\title{
GERAKAN LITERASI SEKOLAH (GLS) MELALUI PEMANFAATAN SUDUT BACA KELAS SEBAGAI SARANA ALTERNATIF PENUMBUHAN MINAT BACA SISWA
}

\author{
Febriana Ramandanu \\ Jurusan Pendidikan Guru Sekolah Dasar, Universitas PGRI Semarang, \\ Jawa Tengah, Indonesia \\ email : febrianaramandanufebru@gmail.com
}

\begin{abstract}
Abstrak
Gerakan Literasi Sekolah (GLS) diselenggarakan berdasarkan sembilan agenda prioritas (Nawacita), dilakukan dengan membudayakan kebiasaan membaca dan menulis. Hal ini sesuai dengan amanat pada Undang-Undang tentang Sistem Pendidikan Nasional (Sisdiknas) No. 20 tahun 2003 pasal 4 ayat 5 yang berbunyi "Pendidikan diselenggarakan dengan mengembangkan budaya membaca, menulis dan berhitung bagi segenap warga masyarakat". Berdasarkan hal tersebut, Kementerian Pendidikan dan Kebudayaan (Kemendikbud) mengembangkan Gerakan Literasi Sekolah (GLS) untuk menumbuhkan budi pekerti siswa agar tercipta budaya literasi di lingkungan sekolah. Kemendikbud (2016:7) menjelaskan Gerakan Literasi Sekolah (GLS) adalah gerakan sosial kolaboratif dengan dukungan berbagai elemen pendidikan. Hal ini menunjukkan bahwa dalam kegiatan Gerakan Literasi Sekolah (GLS) melibatkan warga sekolah (siswa, guru, kepala sekolah, orang tua) dan masyarakat.Hasil penelitian menunjukan bahwa pelaksanaan gerakan literasi sekolah (GLS) di SD Negeri Pamongan 2 Kecamatan Guntur Kabupaten Demak sudah mampu menumbuhkan minat baca siswa dengan program gerakan literasi sekolah (GLS) melalui pemanfaatan sudut baca yang terdapat di setiap kelas. Berdasarkan penelitian ini saran yang dapat disampaikan adalah pelaksanaan gerakan literasi sekolah (GLS) di SD Negeri Pamongan Kecamatan Guntur Kabupaten Demak hendaknya pihak sekolah meningkatkan kerja sama dengan orang tua, masyarkat sekitar dan pemangku kepentingan lain untuk menumbuhkan minat baca siswa.
\end{abstract}

Kata kunci: Gerakan literasi sekolah (GLS), Sudut baca kelas, Minat baca siswa.

\begin{abstract}
The School Literacy Movement is organized based on nine priority agendas, conducted by cultivating the habit of reading and writing. Education is held by developing a culture of reading, writing and counting for all citizens. Based on this, the Ministry of Education and Culture (Kemendikbud) developed the School Literacy Movement to foster students' character in order to create a culture of literacy in the school environment. Kemendikbud (2016: 7) explains the School Literacy Movement is a collaborative social movement with the support of various elements of education. This shows that in the activities of the School Literacy Movement involving school people (students, teachers, principals, parents) and the community. The results showed that the implementation of the school literacy movement in SD Negero Pamongan 2 in Guntur District, Demak Regency had been able to foster students' reading interest with the school literacy movement program through the use of reading corners in each class.Based on this research, the suggestion that can be conveyed is the implementation of the school literacy movement in Pamongan Elementary School, Guntur Subdistrict, Demak Regency. The school should improve cooperation with parents, the surrounding community and other stakeholders to foster students' interest in reading.
\end{abstract}

Keywords: School literacy movement, corner book class, and reading. 


\section{Pendahuluan}

Pendidikan Nasional (Sisdiknas) No. 20 tahun 2003 pasal 4 ayat 5 yang berbunyi "Pendidikan diselenggarakan dengan mengembangkan budaya membaca, menulis dan berhitung bagi segenap warga masyarakat".

Berdasarkan hal tersebut, Kemendikbud mengembangkan GLS untuk menumbuhkan budi pekerti siswa agar tercipta budaya literasi di lingkungan sekolah. Kemendikbud (2016:7) menjelaskan Gerakan Literasi Sekolah (GLS) adalah gerakan sosial kolaboratif dengan dukungan berbagai elemen pendidikan.

Hal ini menunjukkan bahwa dalam kegiatan Gerakan Literasi Sekolah (GLS) melibatkan warga sekolah (siswa, guru, kepala sekolah, orang tua) dan masyarakat. Tujuan dari adanya Gerakan Literasi Sekolah (GLS) salah satunya yaitu untuk menumbuhkan minat baca siswa. Kegiatan penumbuhan minat baca siswa dapat dilakukan di perpustakaan sekolah, sudut baca kelas, dan area baca.

Gerakan Literasi Sekolah merupakan sebuah program pemerintah pusat, melalui Kementerian Pendidikan dan Kebudayaan. Salah satu kegiatan di dalam gerakan tersebut adalah kegiatan 15 menit membaca buku nonpelajaran, sebelum waktu belajar dimulai. Kegiatan ini dilaksanakan untuk menumbuhkan minat baca peserta didik serta meningkatkan keterampilan membaca agar pengetahuan dapat dikuasai secara lebih baik. GLS juga dilaksanakan melalui perpustakaan (tribunpontianak.co.id)

Perpustakaan merupakan sarana penunjang pembelajaran di sekolah. Kalida dan Mursyid (2015:38) menjelaskan bahwa sekolah dan perpustakaan adalah satu-kesatuan yang tidak dapat dipisahkan, hal ini berarti perpustakaan memiliki fungsi sebagai pusat pembelajaran. Selaras dengan itu, Kemendikbud (2016:16) menjelaskan fungsi perpustakaan adalah sebagai pusat pengelolaan pengetahuan dan sumber belajar di sekolah. Perpustakaan SD idealnya berperan dalam mengkoordinasi pengelolaan sudut baca kelas, area baca, dan prasarana literasi lain di SD.

Sudut baca merupakan pemanfaatan sudut ruang kelas sebagai tempat koleksi buku dari para siswa di tiap-tiap kelas. Koleksi buku tersebut ditata secara rapi dan menarik di dalam rak (Alfian Handina Nugroho, Ratna Puspitasari dan Euis Puspitasari, 2016:189).

Sudut baca digunakan sebagai perluasan fungsi perpustakaan, salah satu fungsi perpustakaan yaitu sebagai sumber belajar siswa untuk menambah pengetahuan dan mendapatkan informasi di sekolah (Kemendikbud, 2016:16). Seperti kutipan dari Dauzan Farook dalam Kalida dan Mursyid (2015:4) Buku adalah peluru untuk dijadikan senjata melawan kehidupan, apalagi di zaman globalisasi sekarang ini, senjata utama untuk berperang adalah ilmu dan ilmu dapat diperoleh dengan membaca. Sebuah ungkapan yang menegaskan bahwa membaca memiliki peran penting.

Musfiroh dan Listyorini (2016:5) bahwa membaca sangat penting, karena dengan membaca akan menambah ilmu pengetahuan, meningkatkan kemampuan bahasa, meningkatkan kemampuan berpikir dan berkreasi.

Berdasarkan data yang diperoleh, saat ini Indonesia berada pada kondisi kritis literasi dalam hal minat membaca. Kurniawan (2016:321) menjelaskan bahwa dari hasil penelitian UNESCO, indeks baca nasional pada tahun 2013, angka membaca seluruh Indonesia masih kurang yaitu 0,01 yang artinya 100 orang hanya ada 1 yang gemar membaca. Hasil penelitian melalui PISA (Programme for International Student Assessment) tahun 2012 Indonesia berada pada urutan ke 64 dari 65 negara.

Berpijak dari permasalahan yang muncul di Indonesia tersebut, maka peneliti melakukan penelitian SD Negeri Pamongan 2 Kecamatan Guntur Kabupaten Demak.

Suyono (2009) dengan judul jurnal Pembelajaran Efektif dan Produktif Berbasis Literasi: Analisis Konteks, Prinsip, dan Wujud Alternatif Strategi Pelaksanaannya di Sekolah. Penelitian ini menunjukkan bahwa literasi dapat dijadikan sebagai basis pengembangan pembelajaran efektif dan produktif di sekolah. Siswa terampil membaca dan mengolah informasi, serta kemampuan siswa dalam membaca dan menulis juga berkembang. Siswa juga terampil menghubungkan antar materi pelajaran, lancar mengembangkan gagasan, memahami dan memecahkan masalah. 
Usha Naidoo, Karunanidhi Reddy dan Nirmala Dorasamy (2014) dengan judul jurnal Reading Literacy in Primary Schools in South Africa: Educator Perspective on Factors Affecting Reading Literacy and Strategies for Improvement. Penelitian ini menunjukkan bahwa pendidik harus mengembangkan siswa untuk berpikir kritis, memanfaatkan waktu untuk membaca, melakukan pertemuan informal mingguan untuk membahas kesulitan umum dengan menggunakan alat bantu visual yaitu DVD dan CD.

Evan T. Ortlieb (2010) dengan judul jurnal Beyond Just Book: Sparking Children's Interest in Reading. Penelitian ini menunjukkan bahwa setiap hari selama 15 menit siswa membaca majalah, membaca koran dengan sistem perputaran, artinya siswa membaca secara bergantian. Hal ini menjadikan siswa tidak lagi mengeluh dalam hal membaca dan kegiatan membaca menjadi kegiatan yang menyenangkan.

Peneliti tertarik untuk menyempurnakan penelitian terdahulu dengan melakukan penelitian dengan judul "Gerakan Literasi Sekolah (GLS) melalui pemanfaatan sudut baca kelas sebagai sarana alternatif penumbuhan minat baca siswa".

\section{Metode}

Penelitian ini menggunakan pendekatan kualitatif deskriptif, yaitu penelitian yang berupa deskripsi atau uraian. Penelitian kualitatif dilakukan pada kondisi yang alamiah, langsung ke sumber data dan peneliti adalah instrumen kunci (Sugiyono, 2014:1).

Moleong (2016:6) penelitian kualitatif adalah penelitian yang bermaksud untuk memahami fenomena tentang apa yang dialami oleh subjek penelitian misalnya perilaku, persepsi, motivasi, tindakan secara holistik dan dengan cara deskripsi dalam bentuk katakata dan bahasa, pada suatu konteks khusus yang alamiah dan dengan memanfaatkan berbagai metode alamiah. Arikunto $(2013$ : 172) mengemukakan bahwa sumber data dalam penelitian kualitatif adalah dari mana data dapat diperoleh. Apabila peneliti menggunakan kuisioner atau wawancara dalam pengumpulan datanya, maka sumber data disebut sebagai responden yaitu orang yang merespon atau menjawab pertanyaan-pertanyaan peneliti. Sumber data kualitatif dalam penelitian ini yaitu data yang berupa fakta-fakta yang diperoleh dari observasi, wawancara dan dokumentasi. Moleong (2016:324-330) menjelaskan kriteria keabsahan data dapat diperoleh dari : (1) (credibility), (2) (tranferability), (3) (dependability), (4) (confirmability). Dalam pengecekan data peneliti menggunakan teknik pemeriksaan keabsahan data yaitu triangulasi.

Triangulasi merupakan teknik pemeriksaan keabsahan data yang memanfaatkan sesuatu yang lain. Diluar data itu untuk keperluan pengecekan atau sebagai pembanding terhadap data itu (Moleong, 2016: 330). Peneliti menggunakan teknik ini untuk menghilangkan perbedaan-perbedaan konstruksi kenyataan yang ada dalam konteks suatu studi sewaktu mengumpulkan data tentang berbagai kejadian dan hubungan dari berbagai pandangan. Dengan kata lain, peneliti dapat memeriksa kembali temuannya dengan jalan membandingkannya dengan berbagai sumber, metode, atau teori. Patton (dalam Lexy J. Moleong, 2016:330-331) mengatakan bahwa triangulasi dengan sumber berarti membandingkan dan mengecek balik derajat kepercayaan suatu informasi yang diperoleh melalui waktu dan alat yang berbeda.

Dengan menggunakan teknik ini peneliti dapat membandingkan data hasil pengamatan dengan data hasil wawancara, membandingkan apa yang dikatakan orang di depan umum dengan apa yang dikatakan secara pribadi, membandingkan apa yang dikatakan orang-orang tentang situasi penelitian dengan apa yang dikatakannya sepanjang waktu, membandingkan keadaan dan perspektif seseorang dengan berbagai pendapat dan pandangan orang seperti rakyat biasa, orang berada, orang pemerintahan, dan membandingkan hasil wawancara dengan isi suatu dokumen yang berkaitan.

Sedangkan menurut Patton (dalam Lexy J. Moleong, 2016:331) triangulasi dengan metode terdapat dua strategi, yaitu pengecekan derajat kepercayaan penemuan hasil penelitian beberapa teknik pengumpulan data dan pengecekan derajat kepercayaan beberapa sumber data dengan metode yang sama. 


\section{Hasil dan Pembahasan}

Pelaksanaan GLS di SD Negeri Pamongan 2 pada tahap pembiasaan, berdasarkan hasil penelitian dan pembahasan pelaksanaan gerakan literasi sekolah di SD Negeri Pamongan 2 pada tahap pembiasaan dilakukan melalui kegiatan membaca selama 15 menit sebelum kegiatan pembelajaran dimulai. Kegiatan membaca selama 15 menit merupakan program wajib yang harus diikuti oleh semua warga sekolah.

Hal itu merupakan upaya sekolah untuk menciptakan lingkungan yang mendukung bagi pertumbuhan minat baca anak. Triatma (2016:173) menjelaskan minat baca dipengaruhi oleh faktor dari dalam diri siswa (internal) yang meliputi perhatian, perasaan, dan motivasi, kemudian faktor dari luar siswa (eksternal) yang meliputi peranan guru, lingkungan, keluarga, fasilitas dan faktor lingkungan (di sekolah).

Pelaksanaan kegiatan membaca 15 menit dilakukan dengan memanfaatkan sudut baca yang terdapat di setiap sudut kelas. Sudut baca kelas pada kelas rendah memiliki koleksi buku-buku non pelajaran, diantaranya buku dongeng bergambar kecil sebanyak 60 buah, buku bergambar besar dengan jumlah 50 buah, cerita rakyat bergambar sebanyak 50 buah dan buku kata kartun sebanyak 50 buah. Sementara pada kelas tinggi memiliki sudut baca kelas yang tertata dengan rapi, bersih dan memiliki koleksi buku 16 judul novel dengan jumlah total 20 buku, 2 buku kumpulan puisi dengan jumlah total 18 buku, 5 buku kumpulan pantun dengan jumlah total 24 buku, 18 judul komik dengan jumlah total 60 buku dan majalah bobo sebanyak 24 majalah.

Rahim (2017:85) menyatakan salah satu kegiatan dalam pelaksanaan kegiatan Gerakan Literasi Sekolah tahap pembiasaan adalah memilih buku bacaan. Materi bacaan yang memiliki daya tarik bagi siswa akan memotivasi siswa membaca teks bacaan dengan sungguh-sungguh.

Selaras dengan itu, Kemendikbud (2016:10-22) menjelaskan bahwa memilih materi bacaan dari berbagai macam sumber dimaksudkan agar siswa memiliki wawasan yang luas dan menjadikan membaca sebagai kegiatan yang tidak membosankan. Bahan bacaan yang diberikan kepada kelas rendah dan kelas tinggi berbeda. Kelas rendah lebih menyukai bahan bacaan yang mengandung informasi sederhana, bergambar, bersifat inspiratif dan imajinatif, bergenre fantasi fabel, dan mengandung pesan yang sesuai dengan tahap perkembangan peserta didik kelas rendah. Berbeda dengan peserta didik kelas tinggi yang lebih menyukai bacaan dengan informasi kompleks, inspiratif dan imajinatif, bergenre cerita rakyat, dan mengandung pesan moral sesuai dengan tahap perkembangan peserta didik kelas tinggi.

Selain itu, SD Negeri Pamongan 2 juga memiliki perpustakaan dengan koleksi buku yang variatif, diantaranya komik, novel, cerita rakyat dan majalah anak. Selain itu, perpustakaan juga memiliki fasilitas yang memberikan kenyamanan bagi pengunjungnya. Perpustakaan dilengkapi dengan kipas angin, meja tempat membaca, papan struktur organisasi perpustakaan yang memudahkan pengunjung untuk berkomunikasi perihal perpustakaan sekolah baik meminjam / mengembalikan buku, petugas perpustakaan yang ramah, buku tertata rapi dan memiliki lingkungan perpustakaan yang bersih.

Hal itu dilakukan untuk menumbuhkan minat baca peserta didik. Kemendikbud (2016:10-22) menjelaskan sarana literasi mencakup perpustakaan sekolah, sudut baca kelas dan area baca.

Pengembangan dan penataan perpustakaan kelas, dan area baca menjadi penting dari pelaksanaan GLS di SD dan pengelolaan pengetahuaan yang berbasis pada bacaan. Tempat literasi yang dikelola dengan baik mampu meningkatkan minat baca dan mampu menjadikan warga sekolah sebagai pembelajaran sepanjang hayat.

Pelaksanaan kegiatan membaca 15 menit dilakukan dengan menggunakan metode membaca nyaring dan membaca dalam hati. Membaca nyaring pada kelas rendah, khususnya kelas I dilakukan melalui kegiatan membaca buku dengan suara lantang secara bergantian di depan kelas. Sementara siswa kelas II dan kelas III sudah mulai mampu membaca secara mandiri dengan metode membaca senyap (membaca di dalam hati). 
Membaca senyap dilakukan dengan cara menyampaikan poin-poin buku di jurnal baca yang sudah diisi. Kelas tinggi melakukan kegiatan membaca secara mandiri dengan memilih buku bacaan di sudut baca kelas atau yang telah dibawa dari rumah sesuai pilihan masingmasing. Pada kelas tinggi kegiatan membaca fokus pada kegiatan apresiasi sastra, seperti membaca, menulis dan diskusi tentang puisi, cerpen, pantun dan karya sastra lain. Selain itu pelaksanaan literasi diterapkan melalui program berkarya seni dan sastra. Program berkarya seni dan sastra siswa dilakukan melalui mengisi mading di setiap kelas dengan hasil karya siswa sendiri baik berupa gambar, puisi maupun pantun sederhana.

Hal tersebut menunjukkan kegiatan literasi mampu mengembangkan kemampuan tulis dan lisan peserta didik. Yunus Abidin, Tita Mulyati dan Hana Yunansah (2017 : 280-281) menyatakan kelas berbasis literasi yang kuat diharapkan memunculkan berbagai kegiatan lisan berupa diskusi tentang buku selama pembelajaran di kelas. Kegiatan diskusi ini juga perlu membuka kemungkinan untuk perbedaan pendapat agar kemampuan berpikir kritis dapat diasah.

Pelaksanaan GLS di SD Negeri Pamongan 2 pada tahap pengembangan, Berdasarkan hasil penelitian dan pembahasan pelaksanaan kegiatan literasi di SD Negeri Pamongan 2 sudah berjalan dengan baik, hal ini terlihat dari hasil observasi peneliti bahwa semua warga sekolah melaksanakan kegiatan pembiasaan literasi. Kegiatan literasi tahap pengembangan dilakukan dengan cara menanamkan kebiasaan membaca selama 15 menit sebelum kegiatan belajar mengajar dimulai.

Kegiatan membaca pada kelas rendah dilakukan dengan dua cara, yaitu membaca nyaring terbimbing dan membaca dalam hati. Membaca nyaring terbimbing diterapkan di kelas I dengan menggunakan bahan bacaan buku cerita bergambar yang berukuran besar. Buku bergambar tersebut memuat bahan bacaan sederhana tentang pengenalan kesehatan, lingkungan, keluarga dan benda-benda yang ditemui sehari-hari. Kegiatan membaca nyaring dilakukan dengan cara melibatkan partisipasi dan tanggapan siswa, seperti guru menunjuk siswa untuk membaca nyaring di depan kelas, menulis isi buku atau bahan bacaan di papan tulis dan guru mengajak siswa lain untuk mengoreksinya bersamasama.

Hal itu dilakukan untuk melatih kosa kata sehingga dapat meningkatkan kemampuan membaca peserta didik. Kemendikbud (2016:31-39) menyatakan membaca nyaring interaktif (Interactive read aloud) dilakukan dengan cara guru membacakan buku/ bahan bacaan dan mengajak peserta didik untuk menyimak dan menanggapi bacaan dengan aktif. Proses membacakan buku ini bersifat interaktif karena guru memeragakan bagaimana berpikir menanggapi bacaan dan menyuarakannya (think aloud) dan mengajak peserta didik untuk melakukan hal yang sama. Fokus kegiatan membacakan nyaring interaktif biasanya adalah untuk memahami kosa kata baru.

Membaca dalam hati diterapkan di kelas II dan III dengan menggunakan bahan bacaan buku cerita bergambar dengan ukuran yang lebih kecil. Kegiatan membaca dalam hati dilakukan dengan cara memberikan kebebasan kepada siswa untuk memilih buku bacaan yang disukainya. Setelah memilih buku siswa melakukan kegiatan membaca dalam hati dengan kondusif, kemudian mengisi jurnal baca yang telah disiapkan. Jurnal untuk kelas rendah berisi tentang judul buku, nama pengarang dan kutipan yang menarik di dalam buku.

Hal itu dilakukan untuk menumbuhkan minat baca peserta didik. Kemendikbud (2016:31-39) kegiatan membaca mandiri adalah peserta didik memilih bacaan yang disukainya dan membacanya secara mandiri. Salah satu bentuk kegiatan membaca mandiri adalah membaca dalam hati (Sustained Silent Reading). Sejalan dengan itu, Rahim dalam Triatna (2016:172) menjelaskan bahwa minat baca ialah keinginan kuat yang disertai usaha-usaha seseorang untuk membaca.

Sementara pada kelas tinggi dilakukan dengan cara berdiskusi dan melaksanakan pembelajaran di perpustakaan. Diskusi antara guru dan siswa dilkakukan dalam kegiatan belajar mengajar. Kegiatan diskusi dilakukan dengan membahas isi atau nilai moral yang terdapat dalam suatu karya sastra. Kegiatan diskusi dilakukan untuk melatih siswa berpikir kritis, percaya diri, bertanggung jawab, toleransi dan menghargai orang lain. Kemendikbud 
(2016:31-39) menjalankan melalui diskusi dan apresiasi sastra, peserta didik mampu meningkatkan kemampuan berpikir dan menulis kreatif, baik dalam genre fiksi maupun nonfiksi

Pembelajaran di perpustakaan dilaksanakan seminggu sekali pada hari jumat. Pembelajaran di perpustakaan dilakukan dengan memanfaatkan sudut baca dan perpustakaan sebagai media pembelajaran. Pembelajaran di perpustakaan dilakukan untuk meningkatkan kecakapan literasi perpustakaan peserta didik. Kemendikbud (2016:48) menyatakan pemanfaatan perpustakaan dan sudut baca sekolah bertujuan untuk meningkatkan kecakapan literasi perpustakaan (library literacy) peserta didik. Kecakapan literasi perpustakaan meliputi, pengetahuan tentang fungsi perpustakaan sebagai sumber pengetahuan dan koleksi informasi yang bermanfaat dan menghibur, kemampuan memilih bahan pustaka yang sesuai jenjang dan mina secara mandiri, pengetahuan tentang bahan pustaka sebagai produk karya penulisan yang diciptakan melalui proses kreatif dan pengetahuan tentang etika meminjam bahan pustaka dan berkegiatan di perpustakaan.

Berdasarkan hasil penelitian dan pembahasan tahap pembelajaran gerakan literasi sekolah SD Negeri Pamongan 2 sudah berjalan dengan baik. Hal itu dapat dilihat dari adanya pengayaan yang diterapkan di setiap mata pelajaran. Adapun strategi yang digunakan dalam meningkatkan kemampuan literasi pada siswa kelas rendah adalah menggunakan metode eja dan memanfaatkan media buku bergambar dengan ukuran yang besar.

Buku bergambar dengan ukuran besar tersebut dibaca siswa sesuai dengan bimbingan guru. Guru menunjuk gambar pada buku tersebut kemudian peserta didik bertugas membaca tulisan yang terdapat di gambar sesuai dengan metode eja, yakni menyebutkan tiap huruf dan dieja menjadi suku kata dan menjadi kata yang menerangkan makna gambar yang ditunjuk guru di dalam buku tersebut. Kemendikbud (2016:65) menjelaskan buku pengayaan harus sesuai dengan jenjang kemampuan membaca peserta didik. Selain itu buku yang digunakan harus sesuai dengan tujuan kegiatan pembelajaran.

Sementara pada kelas tinggi guru meningkatkan kemampuan literasi peserta didik menggunakan cara membaca kritis dengan kegiatan mengapresiasi dan menulis sastra. Peserta didik dibimbing untuk berdiskusi mengenai suatu karya sastra. Diskusi tersebut membahas hal-hal yang berkaitan dengan karya sastra, seperti diskusi membahas isi moral yang terkandung dalam karya sastra, menganalisis bahasa kiasan yang digunakan dalam karya sastra dan mengenali perbedaan antara sastra modern dan sastra lama seperti perbedaan bahasa, jumlah bait dan irama dalam puisi.

$\mathrm{Hal}$ itu dapat meningkatkan kemampuan menulis peserta didik. Kemendikbud (2016:65) menjelaskan peserta didik membutuhkan jawaban dan bimbingan untuk pertanyaan-pertanyaan seperti, "Bagaimana memulai menulis?" "Kalimat pertama seperti apa yang baik untuk mengawali tulisan?" Buku cerita anak memiliki aspek literer yang baik karena sudah melalui tahapan pengeditan bahasa dan konten cerita. Karenanya, buku bacaan anak dapat menjadi teks model yang memandu anak untuk mengembangkan struktur kisah (awal-tengah-akhir cerita) dan pilihan kata yang baik.

Peserta didik juga menyuguhkan berbagai penampilan karya sastra, seperti membaca puisi, membaca dongeng dan berpantun di depan kelas. Kemudian guru memberikan penilaian dengan memperhatikan intonasi pengucapan huruf $A, E, O, U$ dan I, cara memainkan irama setiap bait dan penghayatan terhadap karya sastra yang dibacakan. Setiap peserta didik yang berani tampil mendapat penghargaan berupa nilai tambahan.

Berdasarkan hasil penelitian dan pembahasan pelaksanaan Gerakan Literasi Sekolah di SD Negeri Pamongan 2 terdapat program gerakan literasi sekolah yang mewajibkan peserta didik untuk melakukan kegiatan membaca selama 15 menit sebelum kegiatan pembelajaran dimulai. Kegiatan membaca 15 menit dilakukan setiap hari dengan memanfaatkan sudut baca di setiap kelas. Kegiatan 15 menit membaca dilakukan dengan dua cara, yaitu membaca nyaring dan membaca dalam hati. Membaca nyaring diterapkan di kelas rendah untuk melatih kemampuan membaca siswa. Sementara, membaca dalam hati diterapkan di kelas tinggi untuk melatih siswa berpikir krtitis dan mengapresiasi sastra. 
Kemendikbud dalam Buku Panduan Gerakan Literasi Sekolah (2016:10-22) menyatakan bahwa membaca buku selama 15 menit sebelum jam pelajaran dilakukan teknik membaca nyaring biasa dilakukan di kelas rendah. Hal tersebut bertujuan untuk memudahkan peserta didik yang tidak bisa membaca peserta didik dapat membaca nyaring secara mandiri maupun dengan bantuan guru. Kemudian teknik membaca dalam hati biasanya diperuntukkan bagi peserta didik kelas tinggi. Guru menciptakan susasana tenang dan nyaman agar peserta didik dapat berkonsentrasi pada buku yang dibacanya.

Sudut baca yang tersedia di setiap kelas memiliki koleksi buku dengan jumlah ratarata setiap kelas 50 buku dengan judul yang variatif. Pada kelas rendah menggunakan buku cerita bergambar dengan ukuran yang sangat besar. Sementara di kelas tinggi menggunakan buku cerita, puisi, pantun dan cerpen.

Yunus Abidin, Tita Mulyati, Hana Yunansah (2017:280-281) menjelaskan sekolah yang menerapkan program literasi berimbang menyadari bahwa tiap peserta didik memiliki kebutuhan yang berbeda. Oleh sebab itu, strategi membaca dan jenis teks yang dibaca perlu divariasikan, serta disesuaikan dengan jenjang pendidikan. Program literasi yang bermakna dapat dilakukan dengan memanfaatkan bahan bacaan kaya ragam teks, seperti kaya sastra untuk anak dan remaja.

Guru menyusun kegiatan pembelajaran dengan mengintegrasikan kegiatan literasi sekolah. Pembelajaran berbasis literasi di kelas rendah bertujuan untuk melatih kemampuan membaca siswa. Sementara di kelas tinggi dilakukan untuk memperkaya pengetahuan siswa agar dapat melakukan diskusi dan mengapresiasi sastra.

Yunus Abidin, Tita Mulyati, Hana Yunansah (2017:281) menjelaskan Kegiatan literasi pada tahap pelaksanaan pembelajaran berbasis literasi bertujuan untuk mengembangkan kemampuan memahami teks dan mengaitkan dengan pengalaman pribadi, berpikir kritis dan mengolah kemampuan komunikasi secara kreatif. Kegiatan ini dapat dilakukan melalui kegiatan menanggapi teks buku bacaan pengayaan dan buku pelajaran. Dalam tahap ini, ada tagihan yang sifatnya akademis (terkait dengan mata pelajaran). Pada tahap ini, kegiatan membaca dilakukan untuk mendukung pelaksanaan kurikulum 2013, yang mensyaratkan peserta didik membaca buku nonteks pelajaran. Buku nonteks pelajaran ini dapat berupa buku tentang pengetahuan umum, kegemaran, minat khusus atau multimodel serta dikaitkan dengan mata pelajaran lain.

1. Hambatan Pelaksanaan Gerakan Literasi di SD Negeri Pamongan 2

Pelaksanaan gerakan literasi di SD Negeri Pamongan 2 terdapat sedikit hambatan yaitu kurangnya partisipasi orang tua dan masyarakat sekitar dalam menjalankan program kegiatan literasi sekolah. Selain itu, pihak pemerintah dan swasta kurang memberikan dukungan dalam penyediaan sarana dan prasarana penunjang kegiatan literasi. Partisipasi publik seperti komite sekolah, orang tua, alumni sangat diperlukan untuk memelihara dan mengembangkan sarana agar capaian literasi dapat ditingkatkan.

Yunus Abidin, Tita Mulya dan Hana Yunansah (2017:289-296) menjelskan modal dasar terakhir yang harus dimiliki sekolah masa depan adalah sosial budaya masyarakat. Dalam hal ini, sekolah masa depan adalah sekolah yang mampu membentuk kesadaran masyarakat terhadap arti penting pendidikan, yang pada akhirnya masyarakat tergerak untuk berpartisipasi bagi keberhasilan program sekolah.

2. GLS melalui pemanfaatan sudut baca sebagai sarana alternatif penumbuhan minat baca siswa di SD Negeri Pamongan 2

Berdasarkan hasil penelitian dan pembahasan dalam pelaksanaan Gerakan Literasi Sekolah sebagai sarana alternatif penumbuhan minat baca siswa di SD Negeri Pamongan 2 ditemukan adanya siswa yang memilih buku di sudut baca kelas sesuai pilihan masingmasing di SD Negeri Pamongan 2. Sudut baca kelas di SD Negeri Pamongan memiliki koleksi buku yang lengkap dan buku-buku yang disediakan tertata rapi sehingga kemauan dan minat baca anak menjadi meningkat.

Hartyatni (2018:2) menyatakan bahwa sudut baca kelas adalah tempat atau ruangan di sudut kelas yang dilengkapi dengan media yang dapat digunakan untuk melakukan aktivitas membaca, menulis dan berperan sebagai perpustakaan kecil yang mudah dijangkau oleh siswa serta menyenangkan. 
Hasil wawancara mendalam yang dilakukan oleh peneliti, Bapak Janoko selaku kepala sekolah SDN Pamongan 2 menyatakan bahwa sebagian besar siswa sudah menyadari akan kebutuhan membaca. Hal itu tercermin dari banyaknya siswa yang sering bekunjung ke perpustakaan. Selain itu, siswa juga terinspirasi dalam memanfaatkan sudut baca sehingga siswa menjadi sangat antusias dalam melaksanakan kegiatan wajib membaca selama 15 menit sebelum pembelajaran dimulai. Program literasi meningkatkan motivasi siswa untuk melakukan kegiatan membaca.

Hasil kegiatan membaca dapat dilihat dari prestasi dan kemampuan untuk berkarya. Contohnya saja, mading yang terdapat di setiap kelas itu merupakan hasil karya anak-anak. Baik berupa pantun, puisi, cerita bergambar ataupun gambar. Sejalan dengan itu, Ibu Eni Kurnianingsih juga menyatakan bahwa sebagian besar sudah menadari dan suika membaca, tapi di kelas rendah memang masih membutuhkan banyak bimbingan dari guru.

Minat baca siswa SD Negeri Pamongan 2 sudah cukup tinggi, hal itu bisa di lihat dari rata-rata anak meminjam buku setiap minggunya sebanyak 180 buku. Sementara lbu Purna Wistri selaku guru kelas II menyatakan bahwa membaca sangatlah penting karena dengan membaca wawasan dan ilmu pengetahuan akan bertambah. Guru Daliyanti guru kelas V juga mengemukakkan bahwa anak sudah mulai menyadari akan pentingnya membaca, sehingga anak pun menjadi antusias dalam mengikuti kegiatan wajib membaca selama 15 menit. Ibu Murni guru kelas IV memaparkan bahwa hasil membaca sudah bisa dirasakan langsung oleh siswa, siswa yang rajin membaca nilainya pun menjadi meningkat, selain itu siswa juga semakin produktif dalam berkarya. Seperti mengikuti perlombaan menulis maupun mengerjakan tugas dan mengisi mading. Bu siti Sudartati, Bu Sri Rahayu dan Bu Saidatus Rohmanah pun memaparkan hal yang serupa, pada intinya siswa sudah mulai tumbuh minat untuk membaca dan berhasil membuat lingkungan kaya teks secara mandiri melalui mengisi mading yang tersedia di sudut kelas dengan karya peserta didik sendiri.

Hasil observasi juga menunjukan bahwa siswa sudah mulai tumbuh minat membaca. Hal itu dipaparkan siswa melalui wawancara mendalam yang dilakukan oleh penulis. Siswa menyatakan bahwa dirinya suka membaca, dan sangat senang mengikuti serangkaian program sekolah mengenai membaca setiap pagi. Buku yang sangat diminati siswa yaitu buku-buku tentang dongeng dan cerita rakyat. Selain itu, siswa juga menyatakan bahwa dari kegiatan membaca siswa menjadi bisa membuat pantun, puisi, cerita yang dipajang di mading sekolah.

Hal itu menunjukan pelaksanaan gerakan literasi sekolah melalui pemanfaatan sudut baca sebagai sarana alternatif penumbuhan minat baca di SD Negeri Pamongan sudah berjalan secara maksimal dengan acuan indikator minat baca menurut crow and crow dalam hardi (2014:4) meliputi: a) Kebutuhan terhadap bacaan; b) Tindakan untuk mencari bacaan ; c) Rasa senang terhadap bacaan; d) Keinginan selalu untuk membaca; e) Mmenindak lanjuti dari apa yang dibaca.

\section{Simpulan dan Saran}

Berdasarkan penelitian yang telah dilakukan oleh peneliti dapat ditarik sebuah kesimpulan bahwa SD Negeri Pamongan 2 Kecamatan Guntur Kabupaten Demak sudah melaksanakan program Gerakan Literasi Sekolah (GLS). SD Negeri Pamongan 2 sudah memanfaatkan sudut baca dengan optimal. Hal itu dilihat dari keberhasilan sekolah dalam menumbuhkan minat baca siswa. Minat baca di SD Negeri Pamongan 2 Kecamatan Guntur Kabupaten Demak sudah mulai terbentuk. Hal ini karena adanya program Gerakan Literasi Sekolah (GLS) melalui pemanfaatan sudut baca yang terdapat di setiap kelas.

\section{Daftar Pustaka}

Abidin, Yunus dkk. (2017). Pembelajaran Literasi. Jakarta: Bumi Aksara.

Aprilianti, Nenden Ayu dkk. (2016). Hubungan Program 15 Membaca dengan minat kunjung siswa ke perpustakaan di SMP 15 Bandung. Jurnal UPI. Vol (3) No. 2, hal. 142. 
Arikunto,.Suharsimi. (2013). Prosedur Penelitian Suatu Pendekatan Praktik. Jakarta: Rineka Cipta.

Astuti, Muliana Fauziyah. (2013). Pengaruh kedisipilinan belajar dan minat baca terhadap hasil belajar matematika pada siswa kelas XI IPA SMAN Sukoharjo. Universitas Muhamadiyah Surakarta. Hal. 4-5.

Direktur Jendral Pendidikan Dasar dan Menengah. (2016). Panduan Gerakan Literasi Sekolah. Jakarta: Kemendikbud.

(2016). Design Induk Gerakan Literasi Sekolah. Jakarta: Kemendikbud.

Direktur Pembinaan Sekolah Dasar. (2016). Panduan Pemanfaatan dan pengembangan sudut kelas dan area baca sekolah untuk meningkatkan mutu pembelajaran. Jakarta: Kemendikbud.

Haliza, Nur., dkk. (2017). Kemampuan membaca teks pemahaman eksposisi siswa kelas $V$ SD Negeri 5 Banda Aceh. Jurnal Ilmiah Pendidikan Guru Sekolah Dasar. Volume (2). No. 3, hal. 25-27.

Hamid, Abdulloh. (2017). Developing Reading Culture of Madrasah and Pesantren in Surabaya City through Literacy volunteer Student Program. Vicratina. Vol (1). No. 2, hal. 50.

Hardi. (2014). Pengaruh minat membaca buku terhadap hasil belajar mahasiswa BKK Akutansi. Universitas Tanjung Pura Pontianak. Hal, 4.

Hartanti, Afriza Nur. (2013). Hubungan minat baca siswa dengan prestasi belajar siswa program studi keahlian jasa boga SMK N 1 Sewon. Universitas Negeri Yogyakarta. Hal. 35.

Hartyatni, Mijiatun Sri. (2018). Membangun budaya membaca melalui pengelolaan media sudut baca kelas dengan "12345". Jurnal Pemikiran dan Pengembangan SD. Vol (6), Nomor 1, hal 2.

https://www.google.co.id/amp/pontianak.tribunnews.com/amp/2016/11/10/gerakan-literasisekolah-kegiatan-15-menit-membaca-buku-nonpelajaran. Diakses tanggal 6 November 2018 pukul 23:49

Kalida, M dan Mursyid, M. (2015). Gerakan Literasi Mencerdaskan Negeri. Yogyakarta: Aswaja Pressindo.

Kasiun, Suharmono. (2015). Upaya meningkatkan minat baca sebagai sarana untuk mencerdaskan bangsa. Jurnnal Pena Indpnesia. Volume (1). No. 1, hal. 81.

Kurniawan. (2015). Pelaksanaan program motor keliling TBM Mata Aksara di desa Umbulmartani, Ngemplak, Sleman, Yogyakarta. Jurnal Elektronik Mahasiswa PLS Vol. 5, 320 No. 8, hal. 321.

Masruroh, Rizka Viviana. (2017). Skripsi Analisis Pemanfaatan sudut baca di lingkungan sekolah guna menumbuhkan budaya literasi pada siswa di SDN Polomarto. Universitas Muhammadiyah Purwokerto. Hal. 9.

Moleong, Lexy J. (2016). Metodologi Penelitian Kualitatif. Bandung: PT. Remaja Rosdakarya.

Ningrum, Kusuma Pajanti., dkk. (2013). Hubungan anatara minat menjadi guru dan lingkungan keluarga dengan prestasi belajar. Jupe UNS, Vol. 2, No. 1, hal 60. 
Nugroho, Alfian Andina., dkk. (2016) Implementasi gemar membaca melalui program pojok baca dalam mata pelajaran IPS pada siswa kelas VIII SMPN 2 Jember. Jurnal Edueksos Volume V No 2, hal. 201.

Pamungkas, Bintang. (2018). Skripsi Optimalisasi fungsi pojok baca di kelas I SD Muhammadiyah Pangkalpinang sebagai penumbuhkenalkan budaya membaca. Universitas Muhammadiyah Surakarta. Hal. 5.

Pratiwi, Noor Komari. (2015). Pengaruh tingkat pendidikan, perhatian orang tua dan minat belajar siswa terhadap prestasi belajar Bahasa Indonesia siswa SMK kesehatan kota Tangerang. Jurnal Pujangga Volume 1, Nomor 2, hal. 76.

Premana, M, Lutfi Ade. (2017). Pemanfaatan Perpustakaan sebagai Sumber Belajar untuk Meningkatkan Minat Baca Siswa di Perpustakaan Magelang. E.Jurnal Prodi Teknologi Pendidikan. Vol (6), hal. 355.

Prijana.,dkk. (2015). Potensi membaca buku teks. Jurnal kajian dan informasi perpustakaan. Vol (3). No. 1, hal. 82.

Setyono., dkk. ( 2013). Pengembangan Media Pembelajaran Fisika berupa Buletin dalam bentuk Buku Saku untuk Pembelajaran Fisika VII Materi Gaya ditinjau dari minat baca siswa. Journal Pendidikan Fisika. Vol (1), hal. 129-132.

Sugiyono. (2014). Memahami Penelitian Kualitatif. Bandung: Penerbit Alfabeta

Sulasih, R.R Endang Sri (2016). Pengaruh minat membaca karya sastra dan kreativitas terhadap ketrampilan menulis novel. Jurnal Pujangga. Vol (2). No. 2, hal. 85.

Triatma, Nur Ilham. (2016). Minat baca pada kelas VI Sekolah Dasar Negeri Delegan 2 Prambanan Sleman Yogyakarta. E-Jurnal Prodi Teknologi Pendidikan. Vol. (5). No. 6, hal. 172-173.

Undang-Undang Republik Indonesia No. 20 Tahun 2003 tentang Sistem Pendidikan Nasional.

Wandasari, Yulia. (2017). Implementasi Gerakan Literasi Sekolah sebagai pembentuk pendidikan berkarakter. 